\title{
PENGEMBANGAN MULTIMEDIA INTERAKTIF BERBASIS AVENTURE GAME PADA MATERI PRINSIP ANIMSI
}

\author{
Fikri Yandi Kurniawan *, Sardianto Markos Siahaan, Hartono Hartono \\ Universitas Sriwijaya, Jl. Masjid Al Gazali, Palembang, Sumatera Selatan 30128 Indonesia \\ * Corresponding Author. Email: fikri.yandi05@gmail.com \\ Received: 12 December 2019; Revised: 18 December 2019; Accepted: 2 January 2020
}

\begin{abstract}
Abstrak
Pengembangan Multimedia interaktif menggunakan model pengembangan ADIIE Lee dan Owens dan langkahnya dari Aldoobie, mengetahui kevalidan, kepraktisan, dan efektifitas multimedia interaktif terhadap mata pelajaran prinsip animasi. Tahapan Penelitian pengembangan ini terdiri dari tahap analisis, desain, pengembangan, implementasi, dan evaluasi. Multimedia interaktif yang telah dikembangkan kemudian diuji kevalidan oleh ahli, diuji kepraktisan oleh peserta didik, dan diuji efektifitas dengan mengimplementasikan multimedia interaktif di SMK Negeri 5 Palembang. Penilaian terhadap multimedia interaktif ditujukan kepada ahli materi, ahli desain pembelajaran dan ahli media, juga peserta didik sebagai pengguna multimedia interaktif. Dari penelitian pengembangan ini didapatkan bahwa 1.) Multimedia interaktif teruji kevalidan dengan penilaian oleh ahli media terhadap multimedia interaktif sebesar 5 dengan kategori sangat valid, penilaian oleh ahli materi sebesar 4,45 kategori valid, dan penilaian ahli desain pembelajaran sebesar 4,52 kategori valid; 2.) Multimedia di uji one to one oleh 3 siswa dengan kemapuan tinggi sedang dan rendah memberikan tindak lanjut, selanjutnya multimedia interaktif teruji kepraktisannya dengan dengan penilaian Small Group menggunakan 2 kelompok yang terdiri dari 4 orang siswa memahami materi dan 4 orang siswa yang belum begitu memahami materi prinsip animasi dengan hasil efektifitas kelompok 1 nilai $N$-gain 0,69 kategori sedang dengan praktikalitas 4,61 kategori praktis dan kelompok 2 nilai $N$-gain 0,51 degan praktikalitas 4,54 kategori praktis; dan 3.) Multimedia interaktif teruji efektifitas meningkatkan hasil belajar peserta didik dilihat dari adanya gain sebesar 0,70 yang termasuk kedalam kategori tinggi.
\end{abstract}

Kata Kunci: Adventure game, multimedia interaktif, prinsip animasi

\section{DEVELOPMENT OF INTERACTIVE MULTIMEDIA BASED ON ADVENTURE GAME ON ANIMATION PRINCIPLE SUBJECT}

\section{Abstract}

Interactive Multimedia Development using the ADDIE Lee and Owens development model and steps from Aldoobie, to know validity, practicality, and effectiveness interactive multimedia on the subject matter of principal animation. This research development stage consists of the analysis, design, development, implementation, and evaluation phase. Interactive Learning that has been developed and then tested validity by experts, tested practicality by students and tested for effectiveness by implementation interactive multimedia in SMK Negeri 5 Palembang. As for the assessment data of interactive multimedia which is addressed to subject matter experts, learning design experts and media experts, as well as the students as the interactive multimedia users. From this research development, it was found that 1.) The interactive multimedia tested with media experts on interactive multimedia of 5 with a very valid category, the assessment by material experts is 4.45 valid categories, and learning design expert judgment at 4.52 valid categories; 2.) Multimedia was tested one by one by 3 students with moderate to high and low ability to provide and then interactive multimedia proven practicality with the Small Group assessment using 2 groups consisting of 4 students understand the material and 4 students who do not really understand the principles of animation with the results of group 1 effectiveness $N$-gain is 0.69 in the medium category with a practicality of 4.61 in the practical category and group $2 \mathrm{~N}$-gain values 0.51 with practicality of 4.54 practical categories; and 3.) Interactive multimedia has been effectiveness tested to improving students learning outcomes seen from gain of 0.70 included into high category.

Keywords: Adventure game, interactive multimedia, principal of animation

http://dx.doi.org/10.21831/jitp.v6i2.27259

Copyright (02019 Jurnal Inovasi Teknologi Pendidikan ISSN 2407-0963 (print), ISSN 2460-7177 (online)

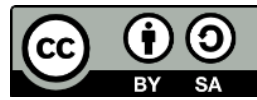




\section{Pendahuluan}

Perkembangan Ilmu Pengetahuan dan Teknologi (IPTEK) di era kini telah berkembang dengan sangat pesat. Perkembangan teknologi di Indonesia didukung oleh pemerintah seperti dalam Instruksi Presiden Nomor 9 Tahun 2016 tentang revitalisasi Sekolah Menengah Kejuruan (SMK) yang bertujuan untuk meningkatan Kualitas dan Daya Saing Sumber Daya Manusia (SDM). Perkembangan teknologi di bidang perfilman berupa pemberian visual efek yang berbentuk Animasi 3 dimensi (3D) dan modeling. Kepercayaan pihak perfilman dunia terhadap sumber daya manusia di Indonesia menjadikan Direktorat Pembinaan SMK membuat suatu program kerjasama antara SMK RUS Foundation Kudus dan beberapa SMK Animasi tanah air untuk meningkatkan kualitas dan daya saing SDM di Indonesia pada kompetensi prinsip animasi.

Peserta didik menjadi peran utama sebagai SDM yang dapat difasilitasi untuk meningkatkan kualitas dan daya saing di bidang prinsip animasi. Pembelajaran prinsip animasi berdasarkan hasil observasi di SMK Negeri 5 Palembang pada tanggal 14 Januari 2019 bahwa kompetensi keahlian peserta didik pada mata pelajaran animasi masih menemui kesulitan pada materi menganalisis dan membuat animasi sesuai dengan 12 prinsip animasi. Praktek pembelajaran tersebut masih dilaksanakan dengan cara konvensional yang mengakibatkan hasil belajar pengetahuan peserta didik terhadap materi tersebut ratanya hanya 68 yang belum mencapai Kriteria Kelulusan Minimal (KKM) yaitu 71. Peserta didik berharap materi menganalisis dan membuat animasi sesuai dengan 12 prinsip animasi dapat lebih mudah dipahami dan dipraktekan, sehingga hasil belajar peserta didik dapat meningkat.

Laboratorium komputer kompetensi keahlian animasi di SMK Negeri 5 Palembang memiliki fasilitas yang sangat mendukung untuk pembelajaran prinsip animasi. Fasilitas tersebut dibuktikan deng- an tersedia komputer yang cukup dan sudah terinstall aplikasi pendukung prinsip animasi memungkinkan guru dapat melaksanakan pembelajaran dengan memanfaatkan sarana dan prasarana sekolah lebih maksimal.

Pembelajaran prinsip animasi mempunyai tujuan agar peserta didik dapat melaksanakan tugas spesifik dengan menggunakan alat, informasi, dan prosedur kerja yang lazim dilakukan serta memecahkan masalah sesuai dengan bidang kerja animasi. Selain itu, mampu menunjukkan keterampilan mempersepsi, kesiapan, meniru, membiasakan, gerak mahir, menjadikan gerak alami dalam ranah konkret terkait dengan pengembangan dari yang dipelajarinya di sekolah, serta mampu melaksanakan tugas spesifik di bawah pengawasan langsung. Penerapan multimedia interaktif sangatlah penting, seperti hasil penelitian oleh Rusli dan Negara (2017, p. 177) yang menyatakan bahwa pembelajaran multimedia interaktif memberikan efek positif dalam meningkatkan hasil belajar siswa, terutama dalam menerapkan konsep, prosedur, dan prinsip-prinsip materi. Penelitian lain yang dilakukan oleh Suryani, Basir, dan Rusmin (2014) menyatakan bahwa multimedia interaktif berbasis komputer model permainan yang dihasilkan telah melewati kriteria ketuntasan klasikal sebesar $85 \%$, sehingga penggunaan multimedia yang dihasilkan termasuk kategori efektif.

Proses pembelajaran yang mengimplementasikan multimedia dapat menggunakan model pembelajaran drill and practice, tutorial, game, simulasi, discovery, dan problem solving (Munir, 2013, p. 68). Multimedia interaktif berbasis game dapat meningkatkan pemahaman dan hasil belajar peserta didik, sehingga tertarik dalam memahami materi menganalisis dan membuat animasi sesuai dengan prinsip animasi. Penelitian games learning memberikan bukti dari studi yang dilakukan dengan fitur permainan instruksional meningkatkan pemahaman, minat, dan pembelajaran peserta didik sangat penting untuk kemajuan 
dalam metode pembelajaran kognitif dan motivasi.

Ramdhani dan Muhtadi (2018, p. 10) mengemukakan bahwa multimedia interaktif memiliki nilai positif, bebagai solusi untuk memecahkan suatu permasalahan yang ditemukan disetiap sekolah. Multimedia interaktif dapat dikembangkan dengan memperhatikan aspek kognitif sesuai dengan kurikulum dan temuan kebutuhan dalam proses pembelajaran. Penggunaan multimedia interaktif memiliki dampak positif pada siswa dalam proses pembelajaran diantaranya proses pembelajaran lebih menarik dan interaktif, efisien tempat dan waktu, siswa menjadi lebih giat, proses belajar mengajar dilaksanakan mandiri dimana saja, serta perhatian siswa dapat lebih fokus dalam proses pembelajaran (Ramadhani \& Muhtadi, 2018, pp. 10-11).

Mutimedia interaktif berbasis adventure game dapat menunjang peserta didik memperoleh pengetahuan atau konsep-konsep melalui pemikirannya sendiri untuk mendapatkan serbuah materi pembelajaran peserta didik atau user diharuskan melewati suatu rintangan yang dapat mempengaruhi kemampuan kognitif peserta didik mendapatkan hasil pengetahuan baru pemberikan pemahaman dengan melakukan penerapan melalui analisis sistematis dari sebuah multimedia interaktif adventure game. Berdasarkan pemaparan tersebut, diperlukan pengembangkan multimedia interaktif yang interaktif berupa game mengenai materi prinsip animasi. Penelitian pengembangan yang dilakukan oleh peneliti diberi judul "Pengembangan multimedia interaktif berbasis adventure game pada mata pelajaran prinsip animasi".

\section{Metode Penelitian}

Penelitian ini merupakan penelitian yang bertujuan untuk mengetahui kevalidan, kepraktisan, dan efektifitas penggunaan multimedia interaktif berbasis adventure game terhadap pembelajaran prinsip animasi. Penelitian yang digunakan adalah penelitian kuantitatif dengan metode pengembangan. Tiga kriteria untuk mengukur kualitas suatu produk yaitu validitas, kepraktisan dan efektifitas. Model pengembangan yang digunakan dalam penelitian ini adalah model pengembangan ADDIE (Lee \& Owens, 2004, p. 3). Tahapantahapan yang dilakukan dalam penelitian ini meliputi tahap analisis (analyze), tahap desain (design), tahap pengembangan (development), tahap implementasi (implementation), dan tahap evaluasi (evaluation).

\section{Prosedur Penelitian}

Penelitian ini menggunakan rancangan dan pendekatan penelitian pengembangan (development research) yang menghasilkan multimedia interaktif berbasis adventure game pada pelajaran prinsip animasi. Model pengembangan yang digunakan dalam penelitian ini adalah model pengembangan ADDIE. Tahapan-tahapan yang dilakukan dalam penelitian ini meliputi tahap analisis (analyze), tahap desain (design), tahap pengembangan (development), tahap implementasi (implementation), dan tahap evaluasi (evaluation). Berdasarkan model pengembangan ADDIE maka tahaptahap penelitian pengembangan (Aldoobie, 2015, pp. 70-71).

Tahap analisis dilaksanakan pada penelitian pendahuluan yang meliputi analisis kebutuhan, analisis karakteristik peserta didik, analisis kurikulum, dan analisis sarana dan prasarana. Analisis ini merupakan langkah awal sebelum melakukan penelitian pengembangan. Dalam hal ini peneliti juga melakukan analisis terhadap hasil belajar didik pada pelajaran prinsip animasi di SMK Negeri 5 Palembang. Pada tahap desain peneliti membuat desain awal multimedia interaktif berbasis adventure game. Desain awal terdiri dari materi pembelajaran, membuat flowchart, membuat storyboard, membuat assets game, gambar, video, menyiapkan suara, dan menentukan software yang akan 
digunakan untuk membuat multimedia interaktif berbasis adventure game.

Tahap pengembangan berupa pembuatan multimedia sesuai storyboard yang telah di desain. Pembuatan multimedia dilakukan dengan menggabungkan assets game, video, gambar, suara dan teks pada aplikasi yang telah ditentukan pada tahap desain. Hasil dari tahap pengembangan berupa multimedia interaktif berbasis adventure game pada pembelajaran prinsip animasi. Tahap implementasi pada penelitian ini, peneliti memulai uji lapangan dengan memberikan soal posttest kepada 1 kelompok atau kelas peserta didik yang hasilnya akan menjadi hasil dari tahap implementasi. Tahap selanjutnya, peneliti mengimplementasikan multimedia interaktif berbasis adventure game pada proses pembelajaran prinsip animasi di SMK Negeri 5 Palembang.

Tahap evaluasi menjadi tahap terakhir dalam penelitian pengembangan ini, bertujuan untuk mengetahui keefektivan multimedia interaktif berbasis adventure game. Hasil tahap evaluasi berupa pembuktian efektifitas berdasarkan peningkatan hasil belajar pengetahuan peserta didik pada mata pembelajaran animasi 3D materi prinsip animasi. Tahap evaluasi terdiri dari pemberian soal postes dan angket respon terhadap multimedia interaktif berbasis adventure game.

\section{Teknik Pengumpulan Data}

Teknik pengumpulan data yang dilakukan dalam penelitian ini adalah wawancara, observasi, angket atau instrumen, dan tes hasil belajar peserta didik. Pada penelitian ini wawancara guru dilakukan pada studi pendahuluan untuk menganalisis kebutuhan dan karakteristik peserta didik, tujuannya guna mengetahui kebutuhan terhadap pemilihan materi yang akan dikembangkan dalam produk multimedia pembelajaran interaktif. Pada tahap ini wawancara dilakukan dengan guru dan peserta didik. Wawancara bersifat terbuka dan terstruktur untuk mendapatkan peni- laian secara langsung. Kisi-kisi wawancara guru terdapat pada Tabel 1.

Tabel 1. Kisi-Kisi Wawancara Guru

\begin{tabular}{lll}
\hline No & Aspek & Pokok Item \\
\hline 1. & Pembelajaran & Hambatan \\
& & Silabus \\
& & RPP \\
& & Media \\
& & Sarana Prasarana \\
& & Isi materi \\
\hline
\end{tabular}

Tujuan observasi adalah untuk mengetahui kesulitan yang dihadapi oleh peserta didik. Observasi digunakan pada kegiatan studi pendahuluan dengan mengamati situasi dan kondisi pembelajaran yang ada dilaksanakan di SMK Negeri 5 Palembang dan pada saat uji lapangan untuk mengetahui aktivitas pembelajaran. Pada penelitian ini angket dilakukan pada tahap uji validasi ahli, dan uji kepraktisan peserta didik. Lembar uji validasi bertujuan untuk mengetahui tingkat kevalidan berdasarkan validator yang ditunjuk sebagai ahli pedagogik, ahli media, dan ahli materi. Lembar uji kepraktisan bertujuan untuk mengetahui tingkat kepraktisan dari multimedia yang dikembangkan yang dinilai oleh peserta didik terpilih berdasarkan tingkat pengetahuan tinggi, sedang dan rendah.

Penelitian ini menggunakan angket yang merujuk pada Learning Object Review Instrument (LORI) version 2.0 oleh Nesbit, Belfer, dan Leacock (2009). Nesbit, Belfer, dan Leacock (2009, p. 2) mengemukakan bahwa penilaian materi meliputi beberapa aspek, yaitu: aspek kualitas isi atau materi (content quality), aspek pembelajaran (learning goal alignment), umpan balik dan adaptasi (feedback and adaptation) dan motivasi (motivation). Tes digunakan untuk mengukur hasil belajar dan mengetahui keefektifan bahan ajar. Efektivitas bahan ajar dapat dilihat dari tercapainya tujuan pembelajaran yang tercermin dari pemahaman konsep siswa. Pemahaman konsep dapat diketahui dengan melakukan penilai- 
an terhadap siswa melalui tes setelah siswa belajar dari bahan ajar berbasis multimedia interaktif. Data tes diambil sebanyak dua kali pada saat evaluasi sebagai pretest dan posttest.

Teknik Analisis Data

\section{Analisis Data Wawancara dan Obserasi}

Analisis data wawancara dan observasi dilakukan dengan cara kualitatif, menurut Sugiyono (2016) penelitian kuantitatif merupakan metode penelitian yang berlandaskan pada filsafat positivisme, digunakan untuk meneliti pada populasi atau sampel tertentu, teknik pengambilan sampel pada umumnya dilakukan secara random, pengumpulan data menggunakan instrumen penelitian, analisis data bersifat kuantitatif. Berdasarkan data yang diperoleh pada penelitian akan dideskripsikan dalam bentuk paragraf. Penilaian multimedia meliputi desain (Presentation desain), kemudahan untuk digunakan (Interaction usability), kemudahan mengakses (Accessibility), kemudahan dimanfaatkan kembali untuk mengembangkan media lain (Reusability) dan memenuhi standar (Strandars compliance). Sedangkan penilaian desain pembelajaran meliputi kualitas isi atau materi (content quality), aspek pembelajaran (learning goal alignment), umpan balik dan adaptasi (feedback and adaptation), dan motivasi (motivation).

Angket atau intrumen dalam penelitian ini menggunakan skala likert yang menggunakan lima kategori yaitu baik sekali (BS), baik (B), cukup (C), kurang (K), dan sangat kurang (SK) (Sugiyono, 2016). Kategori nilai skala likert dapat dilihat pada Tabel 2.

Tabel 2. Kategori Nilai Skala Likert

\begin{tabular}{llllll}
\hline Kategori & BS & B & C & K & SK \\
\hline Jawaban & 5 & 4 & 3 & 2 & 1 \\
\hline
\end{tabular}

Angket atau instrumen untuk menguji kevalidan dinilai oleh ahli. Datadata yang diperoleh akan menjadi hasil penelitian terhadap kevalidan multimedia interaktif berbasis adventure game. Instrumen validasi ahli memiliki lima pilihan jawaban yaitu angka 1 sampai angka 5. Skor yang diperoleh dari para ahli tersebut dicari rata-ratanya dengan menggunakan rumus yang dapat dilihat pada Rumus 1.

$$
M e=\frac{\sum x_{i}}{n}
$$

Sumber: (Sugiyono, 2015, p. 49)

Keterangan: Me adalah Nilai rata-rata, $\sum x_{i}$ Jumlah nilai data, N Banyak data

Nilai rata-rata hasil penilaian para validator selanjutnya diketegorikan kevalidannya yang dapat dilihat pada Tabel 3 .

Tabel 3. Kategori Tingkat Kevalidan

\begin{tabular}{cc}
\hline Skor & Kategori \\
\hline$M e=5$ & Sangat valid \\
$5<M e \leq 4$ & Valid \\
$4<M e \leq 3$ & Cukup valid \\
$3<M e \leq 2$ & Tidak valid \\
$2<M e \leq 1$ & Sangat tidak valid \\
\hline
\end{tabular}

Nilai rata-rata hasil penilaian siswa selanjutnya diketegorikan kepraktisannya yang dapat dilihat pada Tabel 4. Data penelitian yang bersifat kualitatif seperti komentar dan saran akan dijadikan dasar untuk merevisi multimedia interaktif berbasis adventure game.

Tabel 4. Kategori Tingkat Kepraktisan

\begin{tabular}{cc}
\hline Skor & Kategori \\
\hline$M e=5$ & Sangat praktis \\
$5<M e \leq 4$ & Praktis \\
$4<M e \leq 3$ & Cukup praktis \\
$3<M e \leq 2$ & Tidak praktis \\
$2<M e \leq 1$ & Sangat tidak praktis
\end{tabular}

Sumber: (Lestari, Saragih, \& Hasratuddin, 2018, p. 1475)

Pada tahap uji coba produk dilakukan tes terhadap siswa. Tes yang dilakukan berupa pretest, yaitu tes yang dilakukan sebelum pembelajaran menggunakan multimedia interaktif berbasis adventure game dan posttest, yaitu tes yang dilakukan 
setelah pembelajaran menggunakan multimedia interaktif berbasis adventure game. Data yang diperoleh dari hasil pretest dan posttest dihitung menggunakan Rumus 2.

$$
\text { Nilai }=\frac{\text { Skor yang diperoleh }}{\text { Skor Maksimal }} \times 100
$$

Berdasarkan perhitungan dilihat dari masing-masing nilai pretest dan posttest peserta tersebut, selanjutnya digunakan gain yang dinormalisasi N-gain Hake (2002, p. 2). Gain Hake menurut Fadaei (2019, p. 31) dapat digunakan untuk mengukur efektifitas yang relatif dari berbagai teknik pengajaran, begitupun untuk pembelajaran menggunakan multimedia interaktif berbasis adventure game. N-gain dapat dihitung dengan persamaan yang dapat dilihat pada Rumus 3.

$$
N-\text { gain }=\frac{\bar{x} \text { posttest }-\bar{x} \text { pretest }}{100-\bar{x} \text { pretest }}
$$

Keterangan: $\bar{x}$ pretest rata-rata tes awal, $\bar{x}$ posttest rata-rata tes akhir

Untuk mengukur efektivitas multimedia interaktif berbasis adventure game, hasil $N$-gain diinterpretasikan menggunakan Tabel 5.

Tabel 5. Kategori perolehan N-Gain Score

\begin{tabular}{cc}
\hline Kriteria Nilai $N$-gain & Kategori \\
\hline Jika $N$-gain $_{\text {ga }} \geq 0,7$ & Tinggi \\
Jika $0,7>N$-gain $\geq 0,3$ & Sedang \\
Jika $N$-gain $<0,3$ & Rendah \\
\hline
\end{tabular}

Sumber: (Fadaei, 2019, p. 37)

\section{Hasil dan Pembahasan}

Hasil

Pada bagian ini, peneliti menguraikan hasil dan pembahasan yang telah dilakukan mengenai pengembangan multimedia interaktif berbasis adventure game untuk meningkatkan pemahaman prinsip animasi siswa SMK. Penelitian ini diharapkan menghasilkan multimedia interaktif yang valid, praktis dan efektif. Pada bagian metode penelitian, peneliti menggunakan model pengembangan ADDIE yang meliputi tahap analisis (analyze), tahap desain (design), tahap pengembangan (development), tahap implementasi (implementation), dan tahap evaluasi (evaluation) (Lee \& Owens, 2004, p. 3).

\section{Tahap Analisis}

Hasil tahap analisis pada penelitian ini didapatkan dari data wawancara dan observasi di SMK Negeri 5 Palembang terhadap analisis kebutuhan, analisis kurikulum, analisis sarana prasarana, analisis karakteristik siswa dan analisis media. Berdasarkan analisis kebutuhan yang dilakukan dengan wawancara terhadap pendidik atau fasilitator terdapat beberapa temuan, yaitu: 1.) Materi yang disampaikan berupa teks dan gambar (disampaikan berdasarkan buku); 2.) Penyampaiaan materi dengan teks dan gambar saja membuat siswa jenuh dan minim rasa ingin tahu terhadap materi prinsip animasi; dan 3.) Metode pembelajaran yang diterapkan secara umum dilakukan dengan menampilkan teori atau materi pada proyektor, ceramah dan diskusi.

Dengan menerapkan proses pembelajaran tersebut, siswa mengalami kesulitan untuk memahami materi prinsip animasi, karena proses pembelajaran prinsip animasi belum menggunakan multimedia. Hal tersebut memungkinkan kurangnya pemahaman siswa terhadap prinsip animasi, sehingga hasil belajar peserta kurang baik, yaitu dengan nilai pengetahuan rata-rata hanya 68. Siswa cenderung menyukai proses pembelajaran dengan diselingi permainan yang berupa game digital. Oleh karena itu, diperlukan multimedia interaktif berbasis adventure game yang dapat membuat siswa termotivasi dalam mengikuti proses pembelajaran, sehingga pemahaman dan hasil belajar siswa dapat meningkat.

\section{Tahap Desain}

Pada tahap desain, peneliti membuat desain awal multimedia interaktif 
Pengembangan multimedia interaktif berbasis adventure game ... 189

Fikri Yandi Kurniawan, Sardianto Markos Siahaan, Hartono Hartono

berbasis adventure game. Desain awal terdiri dari materi pembelajaran, pembuatan flowchart, pembuatan storyboard, pembuatan assets game, gambar, video, menyiapkan serta menentukan audio yang tepat, dan menentukan software yang akan digunakan untuk mengembangkan multimedia interaktif berbasis adventure game. Penentuan software dispesifikasikan untuk penggunaannya dalam pembuatan flowchart, storyboard, assets game, gambar, teks, video, suara, hingga pengembangan multimedia interaktif. Software yang digunakan dalam penelitian pengembangan ini yaitu: Sistem Operasi Windows, Adobe Photoshop, Adobe lllustrator, DIA Diagram, dan Construct 2 r265.

Sistem operasi berkaitan dengan kebutuhan untuk menjalankan aplikasi yang dipakai dalam mengembangkan dan menggunakan multimedia pembelajaran. Software Adobe Photoshop dan Adobe Illustrator digunakan untuk membuat assets game yang digunakan dalam multimedia pembelajaran, seperti background, button, pembuatan karakter, properti, dan storyboard. DIA Diagram digunakan untuk membuat bagan alur atau flowchart, sedangkan software Construct 2 r265 digunakan untuk mengembangkan multimedia interaktif berbasis adventure game.

Desain flowchart atau diagram alir digunakan untuk memperlihatkan urutan dan hubungan antar proses beserta instruksinya sesuai dengan desain konsep pembelajaran. Urutan serta hubungan antar proses instruksi ini digambarkan dengan simbol-simbol tertentu dan saling terhubung menggunakan garis penghubung. Flowchart didesain menggunakan aplikasi DIA Diagram. Setelah pembuatan flowchart selesai dilakukan, langkah selanjutnya adalah pembuatan storyboard. Storyboard merupakan gambaran rancangan dari sebuah multimedia interaktif yang akan dikembangkan. Storyboard didesain menggunakan software Adobe Illustrator dengan pengaturan kertas berukuran A4. Tahap selanjutnya yaitu membuat assets game, gambar, teks, audio, dan video yang akan di- tampilkan pada multimedia interaktif berbasis adventure game.

\section{Tahap Pengembangan}

Hasil tahap pengembangan pada penelitian ini dilakukan oleh peneliti dengan hasil sebuah multimedia interaktif yang teruji valid dan praktis. Pengembangan dilakukan dengan menggunakan komputer dan aplikasi yang sudah ditentukan. Tahap pengembangan dibagi menjadi beberapa tahapan, diantaranya melakukan uji validasi materi lalu revisi, uji validasi desain pembelajaran lalu revisi, membuat multimedia interaktif, uji validasi ahli lalu revisi, dan melakukan uji praktis atau small group evaluation.

Setelah menyelesaikan pembuatan multimedia interaktif berbasis adventure game, langkah selanjutnya yang dilakukan oleh peneliti adalah meminta penilaian dan saran serta masukan dari ahli dalam hal ini untuk memvalidasi produk yang dikembangkan. Tahap ini merupakan tahap yang penting karena media yang dihasilkan akan dilakukan penilaian oleh ahli untuk mengetahui produk media sudah memiliki kategori valid dan memiliki kelayakan untuk di uji cobakan pada proses pembelajaran. Uji ini melakukan penilaian terhadap aspek materi, aspek pedagogik dan aspek tampilan.

Validasi terhadap ahli materi, mendapatkan nilai dengan rata-rata 4,3 dan masuk kedalam kategori valid dan ahli memberikan saran catatan teks pada tampilan materi yang ditampilkan perhuruf dan perbaikan beberapa kata yang typo. Validasi terhadap ahli desain pembelajaran, mendapatkan nilai dengan rata-rata 4,28 dan masuk kedalam kategori valid. Setelah dilakukan beberapa perbaikan, ahli memberikan saran memperbaiki syntax pembelajaran, materi pembelajaran secara factual, konsep, dan prosedur. Validasi terhadap ahli media mendapatkan nilai dengan rata-rata 5, dan masuk kedalam kategori sangat valid. Dengan tanggapan secara 
keseluruhan game sudah menarik dan layak untuk digunakan.

Setelah menyelesaikan mengembangkan multimedia interaktif berbasis adventure game, langkah selanjutnya yang dilakukan oleh peneliti adalah meminta penilaian dan saran serta masukan dari ahli dalam hal ini untuk memvalidasi produk yang sedang dikembangkan. Tahap ini merupakan tahap yang penting karena media yang dihasilkan akan dilakukan penilaian oleh ahli untuk mengetahui produk media apakah sudah memiliki kategori valid dan memiliki kelayakan untuk di uji cobakan pada proses pembelajaran ataupun masih mendapatkan revisi. Uji validasi ini dilakukan untuk menilai pada aspek materi, aspek pedagogik dan aspek tampilan.

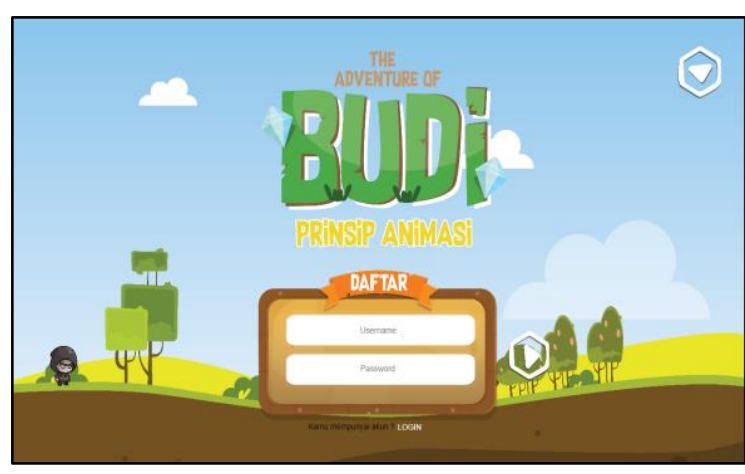

Gambar 1. Tampilan Menu Login

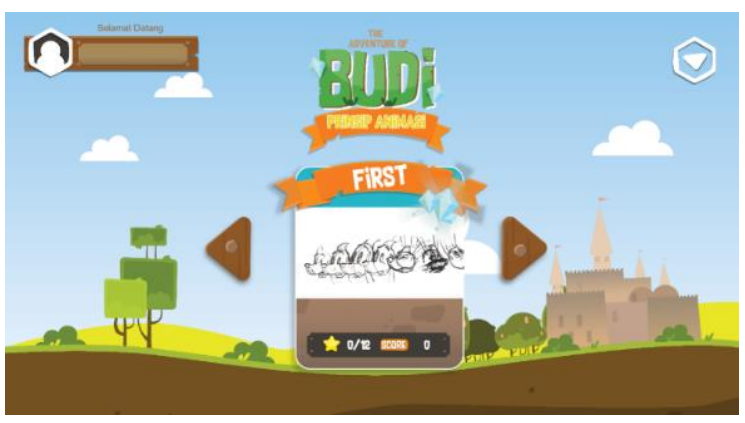

Gambar 2. Tampilan Menu Awal

\section{Uji Validasi dan Revisi}

Validasi terhadap ahli materi, mendapatkan nilai dengan rata-rata 4,3 atau masuk dalam kategori valid dan ahli memberikan saran catatan teks pada tampilan materi ditampilkan perhuruf dan perbaikan beberapa kata yang typo. Validasi terhadap ahli desain pembelajaran, mendapatkan nilai dengan rata-rata 4,28 dan masuk dalam kategori valid, setelah dilakukan beberapa perbaikan, ahli memberikan saran untuk memperbaiki syntax pembelajaran, materi pembelajaran secara faktual, konsep, dan prosedur. Validasi terhadap ahli media mendapatkan nilai dengan rata-rata 5 dan masuk dalam kategori sangat valid, dengan tanggapan secara keseluruhan game sudah menarik dan layak untuk digunakan.

\section{$\underline{\text { Uji Kepraktisan dan Revisi }}$}

Uji kepraktisan dilakukan dengan menggunakan instrumen praktisasi yang telah disiapkan. Intrumen praktisasi meliputi 4 aspek yaitu desain (Presentation design), kemudahan untuk digunakan (Interaction usability), kemudahan mengakses (Accessibility), dan kemudahan dimanfaatkan kembali untuk mengembangkan media lain (Reusability).

Tabel 6. Hasil Kepraktisan Multimedia Interaktif

\begin{tabular}{lcc}
\hline \multicolumn{1}{c}{ Aspek } & Skor Ideal & $\begin{array}{c}\text { Perolehan } \\
\text { Skor }\end{array}$ \\
\hline $\begin{array}{l}\text { Desain } \\
\text { Presentasi }\end{array}$ & 45 & 37 \\
Interaksi & 135 & 110 \\
Pengguna & 45 & 36 \\
$\begin{array}{l}\text { Aksebilitas } \\
\text { Penggunaan }\end{array}$ & 45 & 39 \\
Kembali & & \\
\hline
\end{tabular}

Berdasarkan hasil uji praktisasi kesembilan siswa, multimedia interaktif berbasis adventure game teruji secara praktis dengan memperoleh hasil dengan rata-rata 4,1 dan masuk dalam kategori praktis. Saran yang diperoleh dari uji kepraktisan ini adalah game perlu ditambahkan senjata atau action seperti menembak, perlu untuk memperbaiki tombol navigasi, alangkah lebih baiknya game dapat digunakan secara offline, perlu diberikan teks materi yang lebih cepat, dan perlu dikembangkan game agar dapat digunakan pada komputer dengan spesifikasi rendah. 
Pengembangan multimedia interaktif berbasis adventure game ... 191

Fikri Yandi Kurniawan, Sardianto Markos Siahaan, Hartono Hartono

\section{Tahap Implementasi}

Tahap implementasi dilaksanakan di Laboratorium Animasi dengan melibatkan 30 siswa kelas XI kompetensi multimedia SMK Negeri 5 Palembang. Hasil tahap implementasi berupa analisis nilai pretest dan dokumentasi implementasi multimedia interaktif berbasis adventure game. Tahap ini dilakukan dengan memberikan soal tes awal (pretest) pada awal pertemuan. Pada saat pretest, siswa diberikan soal pilihan ganda sebanyak 30 soal. Rata-rata hasil pretest siswa menunjukkan nilai 32,67 . Setelah siswa melakukan pretest, dilanjutkan dengan menggunakan multimedia interaktif berbasis adventure game pada proses pembelajaran prinsip animasi untuk melakukan uji posttest.

\section{Tahap Evaluasi}

Posttest diberikan kepada siswa setelah mengikuti pembelajaran menggunakan multimedia interaktif berbasis adventure game yang dikembangkan. Pelaksanaan posttest menggunakan soal yang sama pada saat melaksanakan pretest yaitu sebanyak 30 soal yang berkaitan dengan materi prinsip animasi. Penilaian keefektifan diukur dengan menggunakan $\mathrm{N}$-gain sehingga didapatkan dari nilai rata-rata perolehan nilai pretest dan posttest adalah.

$$
\begin{aligned}
& N-\text { gain }=\frac{79,56-32,67}{100-32,67} \\
& N-\text { gain }=\frac{46,89}{67,33} \\
& N-\text { gain }=0,70(\text { tinggi) }
\end{aligned}
$$

Berdasarkan perhitungan di dapat nilai $N$-gain dengan nilai 0,70 kategori tinggi hal ini menunjukan penggunaan multimedia interaktif berbasis adventure game mempunyai dampak efektivitas yang baik terhadap hasil belajar siswa. Peningkatan nilai siswa dari pretest ke posttest menunjukkan bahwa menggunakan multimedia interaktif berbasis adventure game dapat membantu siswa meningkatkan motivasi sehingga pengetahuan siswa meningkat.
Pembahasan

Penelitian ini berhasil mengembangkan multimedia interaktif yang telah teruji valid, berdasarkan hasil uji validasi oleh validator ahli yang menunjukan bahwa multimedia ini memenuhi syarat dari aspek materi, media, dan desain pembelajaran. Pengujian pada aspek materi diperoleh skor dengan hasil rata-rata 4,3 dan masuk dalam kategori valid, aspek desain pembelajaran memperoleh skor dengan hasil rata-rata 4,28 dan masuk ddalam kategori valid, dan validasi media mendapatkan skor dengan nilai rata-rata 5, masuk dalam kategori sangat valid.

Kepraktisan multimedia dibuktikan dengan small group evaluation yang dinilai oleh sembilan orang siswa dengan kemampuan rendah, sedang, dan tinggi. Hasil kepraktisan multimedia interaktif berbasis adventure game mendapatkan skor dengan nilai rata-rata 4,1 dan masuk dalam kategori praktis. Kategori praktis yang diperoleh dari hasil penelitian disebabkan multimedia yang dikembangkan telah memenuhi kebutuhan siswa, karena materinya yang mudah untuk dipahami dan ditampilkan dalam bentuk permainan atau game, sehingga siswa menjadi senang dan termotivasi dalam mengikuti materi pembelajaran yang secara terstruktur terdapat dalam multimedia yang dikembangkan hingga selesai.

Implementasi dan evaluasi multimedia interaktif dilakukan untuk menguji efektifitas dari multimedia interaktif berbasis adventure game yang dikembangkan. Implementasi dilakukan kepada 30 siswa kelas XI Multimedia SMK Negeri 5 Palembang. Sebelum melakukan implementasi multimedia interaktif berbasis adventure game, siswa diberikan 30 soal pretest sebagai nilai awal siswa sebelum mendapatkan pemahaman materi dari multimedia interaktif yang dikembangkan. Hasil pretest menunjukkan rata-rata nilai sebesar 33,67 yang menunjukkan bahwa rata-rata siswa belum memiliki pemahaman atau pengetahuan terhadap materi prinsip animasi. setelah pretest, langkah selanjutnya 
dengan mengimplementasikan multimedia interaktif berbasis adventure game kepada siswa dan memberikan angket respon siswa terhadap multimedia interaktif yang sedang diimplementasikan dalam proses pembelajaran. Tahap evaluasi sebagai tahap terakhir pada model ADDIE (Lee \& Owens, 2004, p. 3). Pada tahap evaluasi, siswa yang telah menggunakan multimedia interaktif berbasis adventure game diberikan 30 soal posttest sebagai nilai akhir setelah menggunakan multimedia interaktif. Hasil nilai pretest dan posttest selanjutnya dianalisis untuk mengetahui keefektifannya. Efektifitas multimedia interaktif berbasis adventure game dapat dilihat dari hasil $\mathrm{N}$-gain (Fadaei, 2019, p. 37).

Multimedia interaktif berbasis adventure game pada materi prinsip animasi berhasil dikembangkan dengan tingkat efektifitas sebesar 0,70 dan masuk dalam kategori tinggi. Hasil respon siswa terhadap multimedia interaktif berbasis adventure game menjadi acuan tingkat efektifitas yang tinggi tersebut. Efektifitas tinggi dipengaruhi oleh tampilan multimedia interaktif berbasis adventure game yang menarik dan materi yang disampaikan dengan diiringi sebuah permainan, sehingga menambah rasa ingin tahu siswa dalam mengikuti dan menyalurkan informasi kepada siswa dari awal hingga materi selesai. Selain itu, materi yang disampaikan baik berupa teks, gambar, dan video pada multimedia interaktif berbasis adventure game sangat mudah untuk dipahami.

Multimedia interaktif berbasis adventure game yang telah dikembangkan oleh peneliti ini relevan dengan penelitian pengembangan sebelumnya yang telah dilakukan oleh Komarudin, Siahaan, dan Sudirman. Multimedia interaktif yang dikembangkan oleh Komarudin, Siahaan, dan Sudirman (2014) menggunakan model Rowntree yang terdiri dari tiga fase yaitu: perencanaan, pengembangan, dan evaluasi. Multimedia diterapkan pada pembelajaran fisika yang dianggap valid dan praktis dengan nilai rata-rata kevalidan $89,82 \%$ dan kepraktisan $86,50 \%$ dan selanjutnya, diim- plementasikan pada siswa kelas XI IPA di SMAN 1 Inderalaya Utara dan menghasilkan keefektifan dengan kategori sedang dengan $N$-gain sebesar 0,5 (Komarudin, Siahaan, \& Sudirman, 2014).

Multimedia interaktif dengan laboratorium virtual yang dikembangkan oleh Setiawan, Isnaeni, Budijantoro, dan Marianti (2015) menghasilkan produk yang dapat meningkatkan prestasi belajar bagi siswa. Multimedia interaktif dikembangkan menggunakan metode research and development (RED) dengan sepuluh pendekatan, yaitu: 1.) Penelitian dan pengumpulan informasi; 2.) Perencanaan; 3.) Pengembangan bentuk awal yang dimaksud produk; 4.) Pengujian lapangan awal dan validasi media oleh para ahli; 5.) Produk utama revisi; 6.) Pengujian lapangan; 7.) Revisi produk operasional; 8.) Pengujian lapangan operasional; 9.) Final revisi produk; dan 10.) Diseminasi dan implementasi. Berdasarkan pendekatan penelitian dan pengembangan yang dilakukan oleh Setiawan, Isnaeni, Budijantoro, dan Marianti (2015, p. 212) dihasilkan sebuah multimedia interaktif yang sangat memenuhi syarat dengan kriteria luar biasa berdasarkan validasi ahli dan pengujian lapangan. Selain itu, multimedia interaktif terbukti dapat meningkatkan prestasi dan kegiatan siswa dengan kriteria aktif sebesar $90,63 \%$.

Multimedia interaktif berbasis adventure game banyak dikembangkan dalam bidang pendidikan yang menimbulkan dampak positif bagi siswa. Seperti pembelajaran berbasis adventure game yang dikembangkan oleh Kwak, Koohang, Floyd, dan Choi (2018) dengan menerapkan konsep literasi seperti pencarian kata kunci, mengindentifikasi, dan mengutip referensi yang tepat. Menurut Kwak, Koohang, Floyd, dan Choi (2018, p. 3616) pembelajaran berbasis adventure game terbagi menjadi tujuh bagian yang diimplementasikan pada siswa. Pengembangan adventure game untuk pembelajaran menunjukkan peningkatan yang signifikan terhadap hasil belajar dan keterampilan literasi siswa. 
Pengembangan multimedia interaktif berbasis adventure game ... 193

Fikri Yandi Kurniawan, Sardianto Markos Siahaan, Hartono Hartono

Hidayanto, Munir, dan Kusnendar (2017, p. 307) memaparkan bahwa pengembangan adventure game sebagai multimedia interaktif dalam pembelajaran dapat dikembangkan menggunakan model ADDIE dengan hasil pemahaman siswa menjadi meningkat dan dikategorikan sedang setelah dilakukan implementasi dari adventure game tersebut. Hidayanto, Munir, dan Kusnendar (2017, p. 307) juga membuktikan bahwa efektifitas adventure game dengan skor hasil tes $N$-gain sebesar 0,59 dalam kategori sedang. Selain itu, respon siswa terhadap multimedia interaktif adventure game dalam pembelajaran sangat baik, dengan persentase aspek perangkat lunak $87,96 \%$, pembelajaran $(88,10 \%)$ dan visual komunikasi $(83,61 \%)$ dengan rata-rata nilai keseluruhannya adalah $86,56 \%$.

Berdasarkan hasil penelitian pengembangan yang dilakukan peneliti dan beberapa hasil penelitian pengembangan yang relevan, maka dapat disimpulkan bahwa multimedia interaktif berbasis adventure game memiliki nilai positif bagi siswa serta dapat meningkatkan hasil belajar siswa. Hasil belajar siswa dipengaruhi dari semangat siswa untuk mendapatkan pembelajaran. Adventure game sangat mempengaruhi semangat belajar siswa, sehingga hasil belajar siswa secara kognitif dapat meningkat. Dalam pengembangan adventure game diperlukan gambar, video, dan teks yang dapat menarik perhatian siswa, sehingga siswa dapat terus termotivasi dalam mengikuti pembelajaran dari awal hingga selesai. Selain itu juga diperlukan fasilitas yang mendukung untuk penggunaan multimedia interaktif di sekolah.

Namun terdapat beberapa kekurangan dalam multimedia interaktif yang dikembangkan oleh peneliti ini. Berdasarkan hasil angket respon yang diberikan kepada siswa terhadap penggunaan multimedia interaktif berbasis adventure game, kekurangan yang didapatkan adalah bahwa multimedia yang dikembangkan hanya dapat digunakan pada komputer dengan spesifikasi yang tinggi, dan masih kurang nya pemahaman dari siswa dalam menggunakan multimedia yang dikembangkan.

\section{Simpulan}

Berdasarkan hasil penelitian dan pembahasan mengenai pengembangan multimedia interaktif berbasis adventure game untuk meningkatkan pemahaman prinsip animasi, ditinjau dari proses pengembangannya, maka dapat disimpulkan bahwa: 1.) Multimedia Interaktif berbasis adventure game telah teruji validitasnya setelah diuji melalui 3 aspek yaitu materi dengan nilai rata-rata 4,3 dan masuk dalam kategori valid, desain pembelajaran dengan nilai rata-rata 4,28 dan masuk dalam kategori valid, dan media dengan rata-rata 5 dan masuk dalam kategori sangat valid. Berdasarkan ketiga kategori tersebut dapat diketahui bahwa multimedia interaktif berbasis adventure game valid dan layak untuk diujicobakan dengan revisi sesuai saran dari para ahli; 2.) Multimedia interaktif berbasis adventure game telah teruji kepraktisannya. Hal ini terlihat dari uji kepraktisan pada 9 orang siswa melalui pengisian angket yang mendapatkan nilai dengan rata-rata 4,1 dan masuk dalam kategori praktis. Tingkat kepraktisan multimedia interaktif berbasis adventure game dinyatakan praktis untuk digunakan pada pembelajaran prinsip animasi; dan 3.) Multimedia Interaktif berbasis adventure game memiliki efektivitas terhadap peningkatan kompetensi siswa yang terlihat dari hasil belajar antara nilai pretest dan posttest.

Pada pretest nilai didominasi pada kategori sangat kurang, sedangkan pada posttest nilai didominasi pada kategori baik, hal ini dinilai sudah sangat efektif yang tergambar pada nilai $N$-gain yang masuk kategori tinggi yaitu 0,70. Tingkat keefektifan dipengaruhi oleh tampilan multimedia interaktif berbasis adventure game yang sangat menarik dan materi yang disampaikan dengan diiringi sebuah permainan yang menambah rasa ingin tahu, sehingga siswa mengikuti penyampaian materi dari awal sampai akhir. Selain itu, materi yang 
disampaikan baik berupa teks, gambar, dan video pada multimedia interaktif berbasis adventure game sangat mudah untuk dipahami.

\section{Daftar Pustaka}

Aldoobie, N. (2015). ADDIE model. American International Journal of Contemporary Research, 5(6), 68-72.

Fadaei, A. S. (2019). Comparing two results: Hake Gain and Dellow Gain, to analyze FCI data in active learning process. US-China Education Review, 9(1), 31-39. doi:https://doi.org/10.17265/2161$\underline{623 X / 2019.01 .003}$

Hake, R. (2002, August). Relationship of individual student normalized learning sains in mechanics with gender, highschool physisc, and pretest scorer on mathematics and spatial visualization. Paper presented at Physic Education Research Conference, Boise, Idaho.

Hidayanto, D. R., Rahman, E. F., \& Kusnendar, J. (2017, October). The application of ADDIE model in developing adventure game-based multimedia learning to improve students' understanding of basic programming. Papere presented at 3rd International Conference on Science in Information Technology (ICSITech), Bandung, Indonesia. doi:https://doi.org/10.1109/ICSIT ech.2017.8257130

Komarudin, U., Siahaan, S., \& Sudirman. (2014). Developing interactive multimedia for physics learning simulation model of gas kinetic theory for Senior High School students grade XI. Paper presented at 2nd SEA-DR, Palembang: FKIP Sriwijaya University.

Kwak, M., Koohang, A., Floyd, K., \& Choi, A. (2018). An educational adventure game for teaching information literacy and student engagement. Paper presented at $51^{\text {st }}$ Hawaii International Conference on System Sciences, Hilton Waikoloa Village, Hawaii.

Lee, W. W., \& Owens, D. L. (2004).

Multimedia based instructional design. San Francisco: Pfeiffer.

Lestari, S. A. B., Saragih, S., \& Hasratuddin, H. (2018). Developing learning materials based on realistic mathematics education with Malay culture context to improve mathematical communication ability and self-efficacy of students in SMPN 2 Talawi. American Journal of Educational Research, 6(11), 14731480.

doi:https://doi.org/10.12691/educ ation-6-11-5

Munir, M. (2013). Multimedia konsep $\mathcal{E}$ aplikasi dalam pendidikan. Bandung: Alfabeta.

Nesbit, J., Belfer, K., \& Leacock, T. (2009). Learning Object Review Instrument (LORI). Retrieved from https://www.academia.edu/79279 07/Learning_Object_Review_Instru ment_LORI

Ramadhani, R., \& Muhtadi, A. (2018).

Development of interactive multimedia in learning Islamic education. International Journal of Multicultureal and Multireligious Understanding, 5(6), 9-15. doi:http://dx.doi.org/10.18415/ijm mu.v5i6.488

Rusli, M., \& Negara, I. K. R. Y. (2017). The effect of animation in multimedia computer based learning and learning style to the learning result. Turkish Online Journal of Distance Education, 18(4), 177-190.

Setiawan, H., Isnaeni, W., Budijantoro, F. P. M. H., \& Marianti, A. (2015). Implementation of digital learning using interactive multimedia in 
Pengembangan multimedia interaktif berbasis adventure game ... 195 Fikri Yandi Kurniawan, Sardianto Markos Siahaan, Hartono Hartono

excretory system with virtual

laboratory. REiD (Research and

Evaluation in Education Journal), 1(2),

212-224.

doi:https:// doi.org/10.21831/reid. $\underline{\mathrm{v} 1 \mathrm{i} 2.6501}$

Sugiyono, S. (2015). Statistika untuk penelitian. Bandung: Alfabeta.

Sugiyono, S. (2016). Metode penelitian pendidikan: Pendekatan kualitatif, kuantitatif dan RED. Bandung:

Alfabeta.

Suryani, A. E., Basir, M. D., \& Rusmin, A. (2014). Pengembangan multimedia interaktif berbasis komputer model permainan pada mata pelajaran ekonomi di SMA Muhammadiyah 1 Palembang. Jurnal Profit, 1(1), 1-13. doi:https://doi.org/10.36706/jp.v1i $\underline{1.5526}$ 